(c) American Dairy Science Association, 2004.

\title{
Production and Metabolic Responses of Periparturient Holstein Cows to Dietary Conjugated Linoleic Acid and trans-Octadecenoic Acids*
}

\author{
K. T. Selberg, ${ }^{1}$ A. C. Lowe, ${ }^{1}$ C. R. Staples ${ }^{1}$, N. D. Luchini, ${ }^{2}$ and L. Badinga ${ }^{1}$ \\ ${ }^{1}$ Department of Animal Sciences, \\ University of Florida, Gainesville 32611, \\ ${ }^{2}$ Bioproducts Inc., Fairlawn, $\mathrm{OH} 44333$
}

\section{ABSTRACT}

Thirty-eight multiparous Holstein cows were utilized in a completely randomized design to examine the effect of feeding calcium salts of conjugated linoleic acid (CLA) and trans-octadecenoic acids $\left(\right.$ trans- $\mathrm{C}_{18: 1}$ ) on animal performance and lipid and glucose metabolism during the transition to lactation. Dietary treatments were initiated approximately $28 \mathrm{~d}$ prior to expected calving dates and continued through d 49 postpartum. Prepartum treatments consisted of 1) a basal diet (Control), 2) basal diet + $150 \mathrm{~g} / \mathrm{d}$ of CLA mix (CLA), and 3) basal diet $+150 \mathrm{~g} / \mathrm{d}$ of trans $-\mathrm{C}_{18: 1} \operatorname{mix}$ (TRANS). Amounts of calcium salts of CLA and trans- $\mathrm{C}_{18: 1}$ mixes were adjusted to $225 \mathrm{~g} / \mathrm{d}$ during the $49-\mathrm{d}$ postpartum treatment period. All diets were offered as a total mixed ration. Prepartum fat supplementation had no detectable effects on dry matter intake, body weight, or body condition score. After parturition, cows in the TRANS group consumed less dry matter at wk 4, 5, and 6 of lactation than did cows in the control group. Cows fed the trans$\mathrm{C}_{18: 1}$ supplement were in a more severe negative energy balance than those fed the control diet at $1 \mathrm{wk}$ of lactation. Periparturient fat supplementation had no detectable effects on milk yield during wk 1 to 7 of lactation. Milk fat was not affected during wk 1 to 4, but was reduced after wk 4 of lactation by dietary CLA. Feeding calcium salts of CLA decreased short- to medium-chain fatty acid $\left(\mathrm{C}_{4}\right.$ to $\left.\mathrm{C}_{14}\right)$ concentrations and increased both linoleic and linolenic acid concentrations in milk fat. Concentrations of nonesterified fatty acids and $\beta$-hydroxybutyric acid in blood were greater in cows fed the CLA-supplemented diet than in those fed the control diet at $1 \mathrm{wk}$ of lactation. In spite of small numerical tendencies, hepatic lipid and triacylglycerol concentrations did not vary significantly among dietary treat-

Received March 7, 2003.

Accepted September 12, 2003.

Corresponding author: L. Badinga; e-mail: Badinga@animal. ufl.edu.

*This manuscript is published as Journal Series No R-09661, University of Florida Agriculture Experimental Station. ments. Periparturient fat supplementation had no detectable effects on plasma glucose and insulin concentrations. Steady-state concentrations of hepatic mRNA encoding pyruvate carboxylase and phosphoenolpyruvate carboxykinase were greater for the TRANS treatment group than the control and CLA groups. Results indicate that dietary CLA and trans $-\mathrm{C}_{18: 1}$ fatty acids may affect lipid and glucose metabolism in early postpartum Holstein cows through distinct mechanisms.

(Key words: conjugated linoleic acid, trans-fatty acid, periparturient, dairy cow)

Abbreviation key: bCLA = basal diet + CLA mix, CLA = conjugated linoleic acid, $\mathbf{P C}=$ pyruvate carbox ylase, $\mathbf{P E P C K}=$ phosphoenolpyruvate carboxykinase, TAG $=$ triacylglycerol, TRANS $=$ fat mixture high in trans- $\mathrm{C}_{18: 1}$ fatty acid isomers.

\section{INTRODUCTION}

Conjugated linoleic acid (CLA) refers to a mixture of positional and geometric isomers of octadecadienoic acids found predominantly in ruminant-derived products (Chin et al., 1992; Ma et al., 1999; Griinari et al., 2000). In rodent models, dietary CLA supplementation has been reported to elicit several positive responses, including reduced tumorigenesis (Ip, 1997), decreased atherogenesis (Nicolosi et al., 1997), enhanced immune response (Cook et al., 1993), increased feed efficiency (Chin et al., 1994), and reduced body fat (DeLany et al., 1999). In lactating dairy cows, supplemental CLA and trans-fatty acids decreased milk fat synthesis (Griinari et al., 1998; Romo et al., 2000; Baumgard et al., 2001) but had minimal effects on DMI and milk protein concentration (Chouinard et al., 1999; Baumgard et al., 2001). The finding that milk fat depression generally corresponds to an increase in milk fat content of the trans-10 octadecenoic isomer has led to the conclusion that the trans-10 fatty acid isomer or its metabolites may be responsible for milk fat depression (Griinari et al., 1998; Baumgard et al., 2000, 2001). Recent studies have provided evidence that the polyunsaturated fatty acids containing trans-10 double bonds likely decrease milk fat percentage through a reduction in de novo fatty 
acid synthesis (Loor and Herbein, 1998; Baumgard et al., 2002). Moallem et al. (2002) recently reported that calcium-protected CLA supplements were more effective at reducing milk fat content than were calcium salts of trans fatty acids. This observation led us to hypothesize that calcium salts of CLA and trans fatty acids may affect production and metabolic responses of transition dairy cows through different mechanisms.

The inability of high-producing dairy cows to maintain a positive energy balance imposes considerable metabolic stress on the lactating animal (Bell, 1995). Failure of the periparturient cow to adequately adjust her metabolism to support the increased nutrient requirements of early lactation may lead to metabolic disorders, suboptimal milk production, and compromised liver function (Grummer, 1993; Drackley, 1999). The objective of this study was to examine the effect of dietary supplementation of calcium salts of CLA and trans $-\mathrm{C}_{18: 1}$ isomers on production and metabolic responses of periparturient Holstein cows.

\section{MATERIALS AND METHODS}

\section{Animals, Treatments, and Sampling}

Thirty-eight multiparous Holstein cows were utilized in a completely randomized design to examine the effect of feeding calcium salts of CLA and trans- $\mathrm{C}_{18: 1}$ fatty acids on animal performance and metabolism during the transition to lactation. All experimental animals were managed according to the guidelines approved by the University of Florida Animal Care and Use Committee. Dietary treatments were initiated approximately $28 \mathrm{~d}$ prior to calculated calving dates and continued through d 49 postpartum. Prepartum treatments consisted of 1) a basal diet (control; $n=17$ ), 2) basal diet + CLA mix (bCLA; Bioproducts Inc., Fairlawn, OH; $\mathrm{n}=10$ ), and 3) basal diet + trans $-\mathrm{C}_{18: 1}$ fatty acid mix (TRANS; Bioproducts Inc.; $\mathrm{n}=11$ ). Fat-supplemented diets were formulated for intakes of approximately 150 $\mathrm{g} / \mathrm{d}$ prepartum and $225 \mathrm{~g} / \mathrm{d}$ postpartum of calcium salts of CLA or trans- $\mathrm{C}_{18: 1}$ mixtures. Each of these salts contains $85.0 \%$ lipids and $10.7 \%$ calcium (Bioproducts Inc.). Fat supplements were mixed with the concentrates and offered as part of the TMR to experimental animals. As a result of adding calcium salts of fatty acids to two of the three diets, experimental diets were not isoenergetic. Detailed fatty acid composition of calcium salts of fat supplements are presented in Table 1 (Bioproducts Inc.).

Prepartum cows were housed in pens with a sod base and equipped with shaded Calan gates (American Calan Inc., Northwood, NH). Postpartum cows were housed in a free-stall barn equipped with fans, sprinklers, and Calan gates. Intake of DM was measured
Table 1. Fatty acid profile of calcium salts of conjugated linoleic acid (CLA) and trans-octadecenoic isomers (TRANS).

\begin{tabular}{|c|c|c|}
\hline Fatty acid & CLA $^{1}$ & TRANS $^{1}$ \\
\hline & \multicolumn{2}{|c|}{$-(\mathrm{g} / 100 \mathrm{~g}$ of fatty acids $)$} \\
\hline $\mathrm{C}_{12: 0}$ & 0.15 & 0.04 \\
\hline $\mathrm{C}_{14: 0}$ & 0.37 & 0.31 \\
\hline $\mathrm{C}_{16: 0}$ & 15.38 & 12.21 \\
\hline $\mathrm{C}_{16: 1}$ & 0.14 & 0.15 \\
\hline $\mathrm{C}_{18: 0}$ & 2.24 & 6.70 \\
\hline $\mathrm{C}_{18: 1}$, trans $6-8$ & $\ldots$ & 20.62 \\
\hline $\mathrm{C}_{18: 1}$, trans -9 & $\ldots$ & 10.47 \\
\hline $\mathrm{C}_{18: 1}$, trans -10 & $\ldots$ & 10.62 \\
\hline $\mathrm{C}_{18: 1}$, trans -11 & $\ldots$ & 7.05 \\
\hline $\mathrm{C}_{18: 1}$, trans -12 & $\ldots$ & 8.73 \\
\hline $\mathrm{C}_{18: 1}$, cis-9 & $\ldots$ & 10.04 \\
\hline $\mathrm{C}_{18: 2}$, cis -9, cis -12 & 34.86 & 1.97 \\
\hline CLA, cis- 8 , trans -10 & 9.18 & $\ldots$ \\
\hline CLA, cis -9, trans -11 & 6.34 & $\ldots$ \\
\hline CLA, cis -11, trans -13 & 8.19 & $\ldots$ \\
\hline CLA, trans -10, cis -12 & 7.88 & $\ldots$ \\
\hline CLA, other & 12.19 & \\
\hline Unknown $^{2}$ & 3.06 & 11.07 \\
\hline
\end{tabular}

${ }^{1}$ Fatty acid composition provided by Bioproducts Inc. (Fairlawn, $\mathrm{OH})$.

${ }^{2}$ Numbers representing fractions of total peak area that have not been identified.

daily. All experimental cows were offered ad libitum amounts of TMR to allow for 5 to $10 \%$ refusals (Table 2 ). Corn silage was the major forage component and ground corn was the primary concentrate. Dry matter of corn silage was determined weekly $\left(55^{\circ} \mathrm{C}\right.$ for $\left.48 \mathrm{~h}\right)$, and the rations were adjusted accordingly to maintain a constant forage:concentrate ratio on a DM basis. Samples of forages and concentrate mixes were collected weekly and composited monthly and analyzed by wet chemistry methods for $\mathrm{CP}, \mathrm{ADF}, \mathrm{NDF}$, and minerals (Dairy One, Ithaca, NY; Table 2).

Postpartum cows were milked 3 times per day and milk weights were recorded at each milking. For each experimental cow, samples of milk from 2 consecutive morning $(1000 \mathrm{~h})$ and evening $(1800 \mathrm{~h})$ milkings were collected weekly at $5,12,19,26,33,40$, and $47 \pm 2$ DIM and analyzed for fat, protein, and SCC. Milk samples were analyzed for fat and protein concentration using a mid-infrared spectrophotometer equipped with an A and B filter (Bentley Instruments, model B2000, Chaska, MN). Two milk samples collected at 8-h intervals provide good estimates of milk fat content of the full day's production for herds milked 3 times per day (Wiggan, 1986). Daily values were calculated by averaging morning and evening milk values. At wk 2,4 , and 7 postpartum, additional milk samples were taken and composited for fatty acid profile determination. Body weights were measured and BCS assigned weekly by the same 2 individuals.

Blood ( 20 mL) was collected weekly at $4,11,18,25$, 32,39 , and $46 \pm 2 \mathrm{DIM}$ via coccygeal arterio-venipunc- 
Table 2. Ingredient and chemical composition of experimental diets.

\begin{tabular}{|c|c|c|}
\hline Ingredient & Prepartum $^{1}$ & Postpartum $^{2}$ \\
\hline \multicolumn{3}{|l|}{ Ingredients, $\%$ of DM } \\
\hline Alfalfa hay & & 10.2 \\
\hline Bermuda grass hay & 13.2 & \\
\hline Corn silage & 39.2 & 28.9 \\
\hline Cottonseed hulls & $\ldots$ & 5.1 \\
\hline Citrus pulp & 11.1 & 6.7 \\
\hline Prolak $^{3}$ & 1.3 & 1.4 \\
\hline Corn meal & 20.0 & 19.9 \\
\hline Soybean meal & 4.2 & 13.6 \\
\hline Whole cottonseed & 5.0 & 9.9 \\
\hline Mineral mix ${ }^{4}$ & 5.5 & 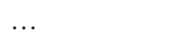 \\
\hline Mineral $\operatorname{mix}^{5}$ & & 4.0 \\
\hline Trace mineralized salt ${ }^{6}$ & 0.6 & 0.2 \\
\hline Feed phosphorus ${ }^{7}$ & $\ldots$ & 0.2 \\
\hline \multicolumn{3}{|l|}{ Chemical composition } \\
\hline $\mathrm{CP}, \%$ of $\mathrm{DM}$ & 12.1 & 18.0 \\
\hline $\mathrm{ADF}, \%$ of $\mathrm{DM}$ & 21.8 & 22.1 \\
\hline $\mathrm{NDF}, \%$ of $\mathrm{DM}$ & 36.2 & 32.2 \\
\hline $\mathrm{NFC}, \%$ of DM & 39.1 & 36.7 \\
\hline Ether extract, \% of DM & 4.3 & 5.2 \\
\hline $\mathrm{NE}_{\mathrm{L}}, \mathrm{Mcal} / \mathrm{kg}$ of $\mathrm{DM}^{8}$ & 1.54 & 1.65 \\
\hline $\mathrm{Ca}, \%$ of $\mathrm{DM}$ & 1.75 & 0.35 \\
\hline $\mathrm{Mg}, \%$ of $\mathrm{DM}$ & 0.30 & 0.32 \\
\hline $\mathrm{K}, \%$ of $\mathrm{DM}$ & 1.12 & 1.36 \\
\hline $\mathrm{Na}, \%$ of $\mathrm{DM}$ & 0.25 & 0.40 \\
\hline $\mathrm{S}, \%$ of $\mathrm{DM}$ & 0.22 & 0.20 \\
\hline $\mathrm{Fe}, \mathrm{mg} / \mathrm{kg}$ of $\mathrm{DM}$ & 402 & 406 \\
\hline $\mathrm{Zn}, \mathrm{mg} / \mathrm{kg}$ of $\mathrm{DM}$ & 92 & 106 \\
\hline $\mathrm{Cu}, \mathrm{mg} / \mathrm{kg}$ of $\mathrm{DM}$ & 18 & 29 \\
\hline $\mathrm{Mn}, \mathrm{mg} / \mathrm{kg}$ of $\mathrm{DM}$ & 63 & 76 \\
\hline Mo, mg/kg of DM & 1 & 1 \\
\hline
\end{tabular}

${ }^{1}$ Diets contained 0 or $1.44 \%$ of calcium salts of conjugated linoleic acids (CLA), or $1.44 \%$ of calcium salts of trans-octadecenoic fatty acid mixture (DM basis). The calcium salt products partially replaced cornmeal.

${ }^{2}$ Diets contained 0 or $1.29 \%$ of calcium salts of CLA, or $1.29 \%$ of calcium salts of trans-octadecenoic fatty acid mixture (DM basis). The calcium salt products partially replaced cornmeal.

${ }^{3} \mathrm{~A}$ marine and animal protein supplement containing $68 \%$ RUP (H. J. Baker \& Bro., Inc., Stamford, CT).

${ }^{4}$ Mineral and vitamin mix contained $22.8 \% \mathrm{CP}, 2.1 \%$ fat, $22.89 \%$ $\mathrm{Ca}, 0.16 \% \mathrm{P}, 2.77 \% \mathrm{Mg}, 0.75 \% \mathrm{Na}, 0.20 \% \mathrm{~K}, 2.42 \% \mathrm{~S}, 8.03 \% \mathrm{Cl}, 146.7$ $\mathrm{mg} / \mathrm{kg}$ of Mn, $95.0 \mathrm{mg} / \mathrm{kg}$ of $\mathrm{Zn}, 26.6 \mathrm{mg} / \mathrm{kg}$ of $\mathrm{Fe}, 112.5 \mathrm{mg} / \mathrm{kg}$ of $\mathrm{Cu}$, $10.7 \mathrm{mg} / \mathrm{kg}$ of Co, $7.9 \mathrm{mg} / \mathrm{kg}$ of I, $6.9 \mathrm{mg} / \mathrm{kg}$ of Se, $268,130 \mathrm{IU} / \mathrm{kg}$ of vitamin A, 40,000 IU/kg of vitamin D, and $1129 \mathrm{IU} / \mathrm{kg}$ of vitamin $\mathrm{E}$ (DM basis).

${ }^{5}$ Mineral and vitamin mix contained $26.4 \% \mathrm{CP}, 1.74 \%$ fat, $10.15 \% \mathrm{Ca}, 0.90 \% \mathrm{P}, 3.1 \% \mathrm{Mg}, 8.6 \% \mathrm{Na}, 5.1 \% \mathrm{~K}, 1.5 \% \mathrm{~S}, 4.1 \% \mathrm{Cl}$, $2231 \mathrm{mg} / \mathrm{kg}$ of Mn, $1698 \mathrm{mg} / \mathrm{kg}$ of Zn, $339 \mathrm{mg} / \mathrm{kg}$ of Fe, $512 \mathrm{mg} / \mathrm{kg}$ of $\mathrm{Cu}, 31 \mathrm{mg} / \mathrm{kg}$ of Co, $26 \mathrm{mg} / \mathrm{kg}$ of I, $7.9 \mathrm{mg} / \mathrm{kg}$ of Se, $147,756 \mathrm{IU} / \mathrm{kg}$ of vitamin A, 43,750 IU/kg of vitamin D, and $787 \mathrm{IU} / \mathrm{kg}$ of Vitamin E (DM basis).

${ }^{6}$ Minimum concentrations of $40 \% \mathrm{Na}, 55 \% \mathrm{Cl}, 0.25 \% \mathrm{Mn}, 0.2 \%$ $\mathrm{Fe}, 0.033 \% \mathrm{Cu}, 0.007 \% \mathrm{I}, 0.005 \% \mathrm{Zn}$, and $0.0025 \%$ Co (DM basis). Manufactured by Flint River Mills, Inc., Bainbridge, GA.

${ }^{7}$ Contains $21 \% \mathrm{P}$ and 15 to $18 \% \mathrm{Ca}$. Manufactured by Southeastern Minerals, Inc., Bainbridge, GA.

${ }^{8} \mathrm{NE}_{\mathrm{L}}$ values for prepartum and postpartum diets containing calcium salts were 1.58 and $1.69 \mathrm{Mcal} / \mathrm{kg}$ of dietary DM, respectively.

ture into potassium oxalate- and sodium fluoride-coated tubes (Vacutainer, Becton Dickinson, Franklin Lakes, NJ) just before the morning feeding (0700 h). Samples were placed immediately in ice and centrifuged at 3000 $\times g$ for $30 \mathrm{~min}$. Plasma was harvested and stored at $-20^{\circ} \mathrm{C}$ for subsequent metabolite and hormone analyses. On d 2, $14 \pm 2$, and $28 \pm 2$ postpartum, liver samples were collected via biopsy, rinsed with sterile saline, snap-frozen in liquid nitrogen, and stored at $-80^{\circ} \mathrm{C}$ until analyzed for lipid metabolites and mRNA abundance.

Prepartum energy balance was calculated using the following equation:

Energy balance $=$ net energy of intake - (net energy of maintenance + net energy of pregnancy).

Net energy of intake was calculated by multiplying the weekly DMI by the calculated energy value of the diet. Energy requirement for body maintenance was computed using the following equation (NRC, 2001):

$$
\text { Net energy of maintenance }=0.08 \times \mathrm{BW}^{0.75}
$$

Pregnancy requirements were estimated using the following equation (NRC, 2001):

Net energy of pregnancy $=[(0.00318 \times$ days pregnant $-0.0352) \times($ calf BW/45) $] / 0.218$

Postpartum energy balance was estimated using the following equation (NRC, 2001):

Energy balance $=$ net energy of intake - (net energy of maintenance + net energy of lactation)

Milk energy was estimated by the following equation:

Net energy of lactation $=[(0.0929 \times \%$ fat $)+(0.0547 \times$ $\%$ protein $)+0.192] \times$ milk weight

\section{Chemical Analyses}

Milk fat was extracted following the method of Sukjija and Palmquist (1988), and fatty acid methyl esters were formed using a methanolic sodium methoxide solution (Christie, 1982). Fatty acid methyl esters were separated by a gas-liquid chromatograph (HewlettPackard 6890 series with auto injector), as described by Giesy et al. (2002). Briefly, fatty acid profile was determined by split injection (20:1) onto a CP-Sil 88 fused-silica capillary column $(100 \mathrm{~m} \times 0.25 \mathrm{~mm}$; Chrompack, Raritan, NJ) using a programmed temperature gradient method. The hydrogen carrier gas pressure was constant and the injector and detector temperatures were $255^{\circ} \mathrm{C}$. Initial oven temperature was $70^{\circ} \mathrm{C}$. Following injection of sample, the oven temperature 
was increased by $4^{\circ} \mathrm{C} / \mathrm{min}$ to $175^{\circ} \mathrm{C}$ and held for $3 \mathrm{~min}$. Oven temperature was then raised by $1^{\circ} \mathrm{C} / \mathrm{min}$ to $185^{\circ} \mathrm{C}$ and held for $20 \mathrm{~min}$. Oven temperature was then increased by $3^{\circ} \mathrm{C} / \mathrm{min}$ to $215^{\circ} \mathrm{C}$ followed by an increase by $10^{\circ} \mathrm{C} / \mathrm{min}$ to $240^{\circ} \mathrm{C}$ and held for $5 \mathrm{~min}$. Oven temperature was subsequently returned to $70^{\circ} \mathrm{C}$. Individual fatty acids were identified by comparison of retention times to those of pure standards (Matreya, Inc., Pleasant Gap, PA). A response correction factor for each fatty acid methyl ester was used to convert peak area percentage to weight percentage. Correction factors were determined by analyzing butter oil of a known fatty acid profile with certified values (CRM 164; European Community Bureau of Reference, Brussels, Belgium; Giesy et al., 2002).

Concentrations of NEFA (NEFA-C kit; Wako Fine Chemical Industries USA, Inc., Dallas TX), glucose (Sigma procedure no. 510; Sigma Chemical Co., St. Louis, MO), and BHBA (Sigma procedure No. 319; Sigma Chemical Co., St. Louis, MO) in plasma were measured enzymatically with commercially available kits. Intraassay coefficients of variation were 4.8, 2.4, and $3.5 \%$ for plasma NEFA, glucose, and BHBA, respectively. Hepatic lipid was extracted from finely homogenized liver with a 2:1 (vol/vol) mixture of chloroform and methanol, and concentrations of total lipids were determined gravimetrically after drying under $\mathrm{N}_{2}$ (Drackley et al., 1991). The lipid extract was redissolved in 3:2 (vol/vol) mixture of hexane and isopropanol, and concentrations of triacylglycerol (TAG) were measured colorimetrically as described by Foster and Dunn (1973). The concentration of insulin in plasma was measured using the double-antibody radioimmunoassay procedure described by Malven et al. (1987). Sensitivity of the assay was $1 \mathrm{ng} / \mathrm{ml}$, and intra- and interassay coefficients of variation were 2.7 and $6.9 \%$, respectively.

Total liver cellular RNA was isolated from a subset of 5 animals per treatment group using TRIzol reagent (Life Technologies, Grand Island, NY). Total RNA (30 $\mu \mathrm{g})$ was fractionated in a $1.0 \%$ agarose-formaldehyde gel and blotted to a Biotrans nylon membrane (ICN, Irvine, CA) via capillary action. The RNA was crosslinked to the membrane by UV irradiation and baked at $80^{\circ} \mathrm{C}$ for $1 \mathrm{~h}$. The RNA blots were prehybridized with Rapid-Hyb buffer (Amersham-Pharmacia Biotechnology, Piscataway, $\mathrm{NJ}$ ) at $60^{\circ} \mathrm{C}$ for $30 \mathrm{~min}$. The filters were then hybridized with random primer-labeled pyruvate carboxylase (PC) and phosphoenol pyruvate carboxykinase (PEPCK) cDNA probes (Feinberg and Vogelstein, 1983). After hybridization, RNA filters were washed for $20 \mathrm{~min}$ in $50 \mathrm{ml}$ of $2 \times$ saline sodium citrate, $0.1 \%$ SDS at room temperature, followed by two 15 -min washes in $0.1 \times$ saline sodium citrate and $0.1 \%$ sodium dodecyl sulfate at $42^{\circ} \mathrm{C}$. The filters were blotted dry and exposed
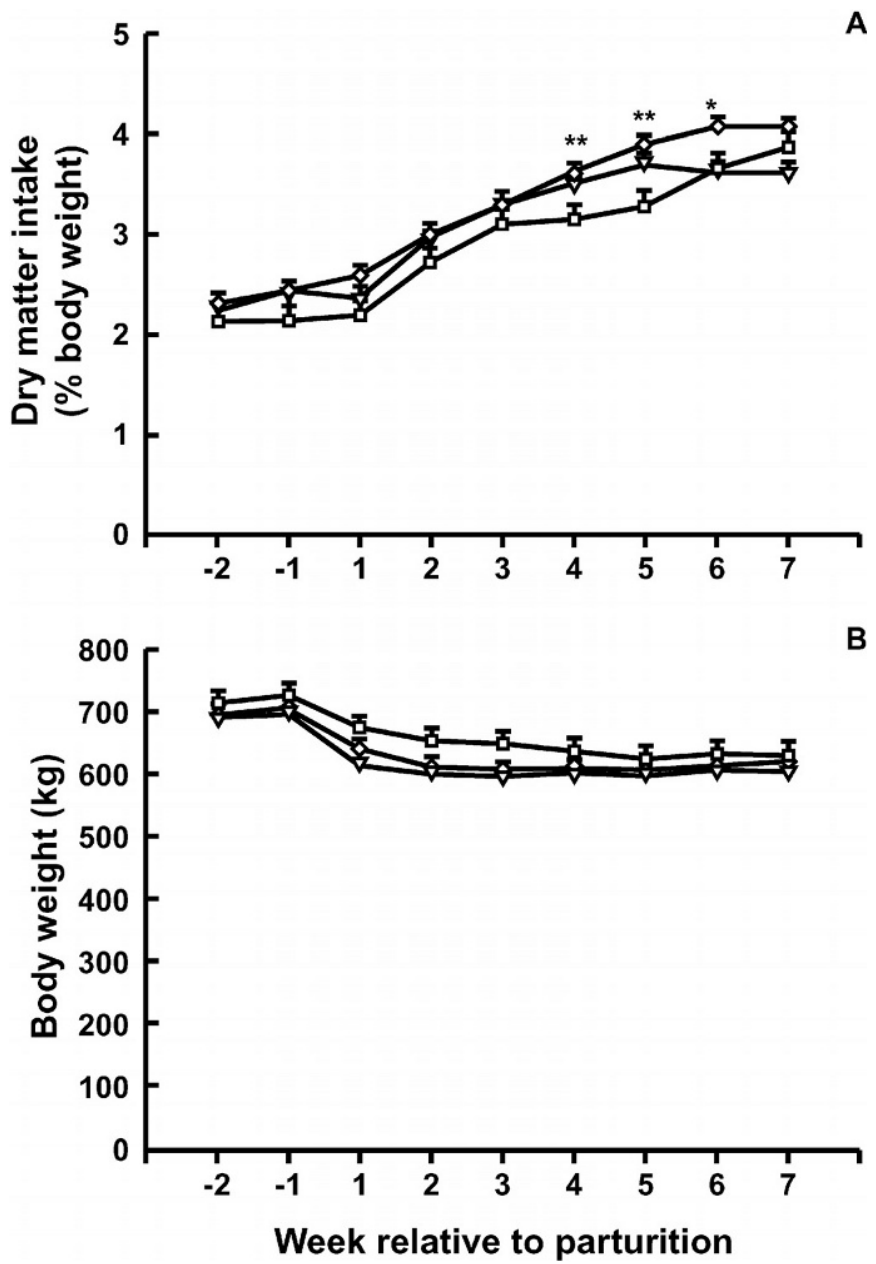

Figure 1. Average DMI (A) and BW (B) of postpartum Holstein cows fed a control (O), conjugated linoleic acids (CLA)-supplemented $(\nabla)$, or trans $-\mathrm{C}_{18: 1}$ (TRANS)-supplemented ( $\square$ ) diet. See Table 1 for composition of fat supplements. Asterisks indicate significant treatment differences at wk $4(P<0.01), 5(P<0.01)$, and $6(P<0.02)$ of lactation for DMI.

to x-ray film (X-OMAT, Eastman Kodak, Rochester, $\mathrm{NY}$ ) for 24 to $48 \mathrm{~h}$ at $-80^{\circ} \mathrm{C}$. Hybridization signals for each target gene were quantified by densitometric analysis. Equal loading of RNA samples and specificity of treatment effects were verified by subsequent rehybridization of filter membranes with glyceraldehyde 3-phosphate dehydrogenase probe.

\section{Statistical Analyses}

Performance and intake responses were reduced to weekly means before statistical analysis. Production and metabolic responses were evaluated using the MIXED procedure for repeated measurement of the SAS software package (SAS Inst., Inc., Cary, NC). Fixed effects included treatment, week relative to calving, 


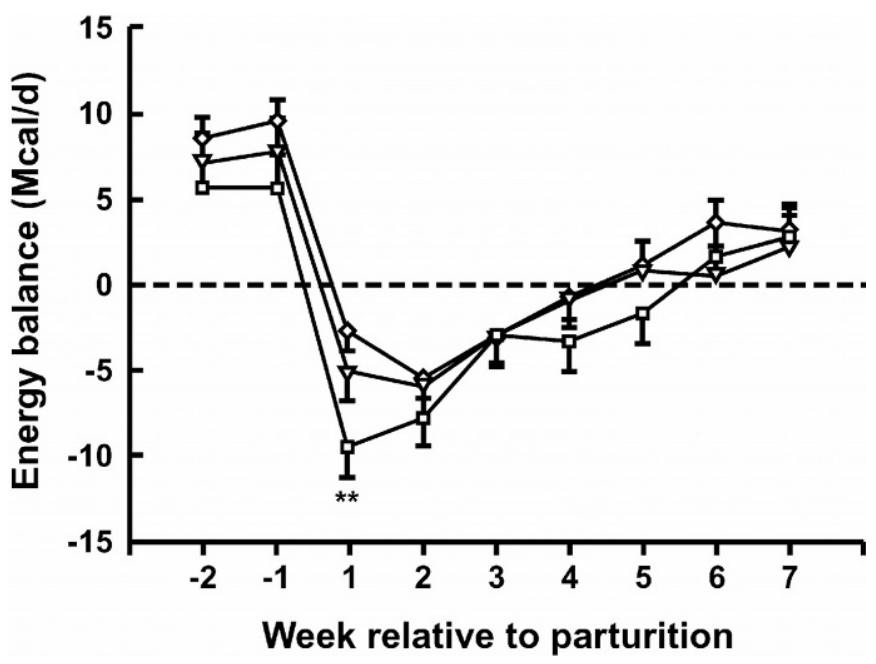

Figure 2. Calculated energy balance by week relative to parturition for Holstein cows fed a control $(\bigcirc)$, conjugated linoleic acidssupplemented $(\nabla)$, or trans- $\mathrm{C}_{18: 1}$ (TRANS)-supplemented ( $\square$ ) diet. The asterisk indicates significant treatment differences $(P<0.01)$ at wk 1 of lactation.

and treatment $\times$ week interaction. The variance for cow, nested within treatment, was used as random error term to test the main effect of treatment. Effects of CLA or trans- $\mathrm{C}_{18: 1}$ supplementation were examined by single degree of freedom contrasts (control vs. CLA or control vs. TRANS). Differential temporal responses to dietary treatments were further examined using the SLICE option of the MIXED procedure. Liver metabolite and mRNA responses were analyzed using the MIXED procedure with mathematical models that included effects of treatment, sampling day, and treatment $\times$ day interaction. The cow variance was considered random and was utilized as the error term to test the main effect of treatment. Mean treatment and week effects are reported as least squares means.

\section{RESULTS}

\section{Production Responses}

Dry matter intakes $(15.8 \pm 0.7 \mathrm{~kg} / \mathrm{d}), \mathrm{BW}(695.7 \pm 21$ $\mathrm{kg})$, and BCS (3.10 \pm 0.10$)$ were similar for all 3 dietary treatment groups during the prepartum period. Average intakes of calcium salts of CLA and trans $-\mathrm{C}_{18: 1}$ isomers were 231 and $214 \mathrm{~g} / \mathrm{d}$, respectively, during the prepartum period. Corresponding values were 258 and $261 \mathrm{~g} / \mathrm{d}$ for the CLA and trans- $\mathrm{C}_{18: 1}$ mixes, respectively, during the 49-d postpartum treatment period.

Postpartum DMI increased $(P<0.01)$ from $2.4 \%$ of BW at wk 1 to $3.9 \%$ of BW at wk 7 of lactation (Figure 1A). Compared with the control group, cows in the TRANS treatment group consumed less DM at wk 4 $(0.5 \% \mathrm{BW}, P<0.01), 5(0.6 \% \mathrm{BW}, P<0.01)$ and $6(0.4 \%$ $\mathrm{BW}, P<0.02$ ) of lactation (Figure $1 \mathrm{~A}$ ). On average, cows in the bCLA treatment group consumed less DM $(P<$ 0.02 ) than control cows at wk 6 of lactation (Figure 1A). Although cows in the TRANS group tended to have greater BW than cows in the other two treatment groups, patterns of BW response did not vary among dietary groups (Figure 1B). Cows fed the trans- $\mathrm{C}_{18: 1^{-}}$ supplemented diet were in a more negative energy balance $(P<0.01)$ at wk 1 of lactation than cows in the control group (Figure 2).

Average milk production during the 7-wk postpartum treatment period did not differ among the dietary groups (Table 3). Milk production pattern for cows in the TRANS treatment group was different (treatment

Table 3. Least squares means for performance of lactating Holstein cows fed diets containing calcium salts of conjugated linoleic acid (CLA) or trans-octadecenoic acid isomers (TRANS) during wk 1 through 7 of lactation.

\begin{tabular}{|c|c|c|c|c|c|c|}
\hline \multirow[b]{2}{*}{ Measurement } & \multicolumn{3}{|c|}{ Treatment } & \multirow[b]{2}{*}{ SEM } & \multicolumn{2}{|c|}{ Contrasts $^{1} P$} \\
\hline & Control & CLA & TRANS & & C1 & $\mathrm{C} 2$ \\
\hline \multicolumn{7}{|l|}{ Performance } \\
\hline DMI, kg/d & 21.6 & 20.0 & 20.2 & 0.82 & 0.15 & 0.24 \\
\hline Milk, kg/d & 40.3 & 41.5 & 41.5 & 1.88 & 0.62 & 0.66 \\
\hline $3.5 \%$ FCM, kg/d & 40.0 & 37.4 & 40.5 & 2.11 & 0.35 & 0.87 \\
\hline BW, kg & 617 & 606 & 644 & 17.65 & 0.64 & 0.28 \\
\hline BCS & 2.6 & 2.6 & 2.6 & 0.1 & 0.79 & 0.59 \\
\hline \multicolumn{7}{|l|}{ Milk components } \\
\hline \multicolumn{7}{|l|}{ Milk fat } \\
\hline$\%$ & 3.49 & 2.99 & 3.46 & 0.13 & 0.01 & 0.88 \\
\hline $\mathrm{kg} / \mathrm{d}$ & 1.38 & 1.19 & 1.39 & 0.08 & 0.11 & 0.99 \\
\hline \multicolumn{7}{|l|}{ Protein } \\
\hline$\%$ & 2.89 & 2.82 & 2.81 & 0.07 & 0.44 & 0.37 \\
\hline $\mathrm{kg} / \mathrm{d}$ & 1.14 & 1.15 & 1.12 & 0.05 & 0.95 & 0.81 \\
\hline SCC $(\times 1000)$ & 509 & 245 & 356 & 180 & 0.29 & 0.54 \\
\hline
\end{tabular}

${ }^{1}$ Contrasts: $\mathrm{C} 1$ = control vs. CLA; C2 = control vs. TRANS. 

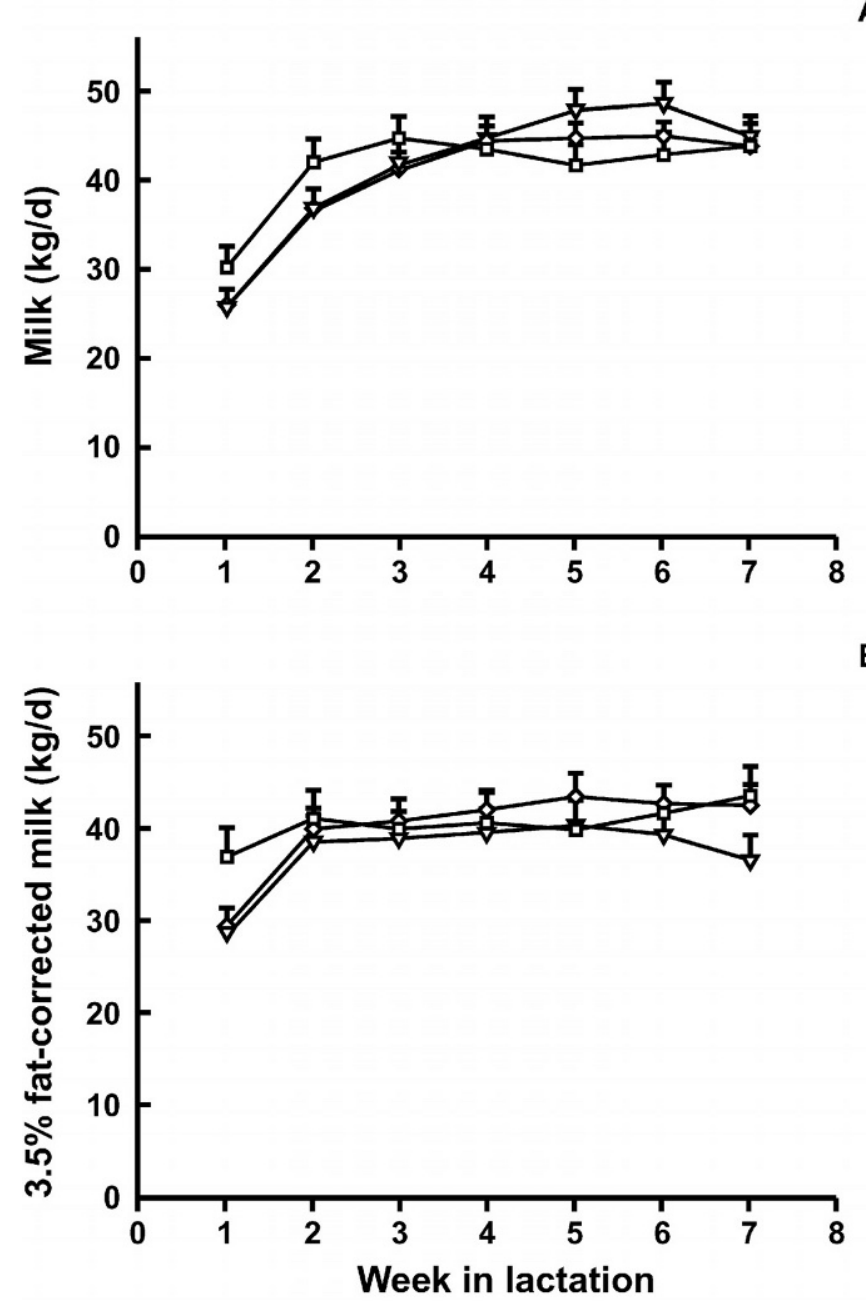

Figure 3. Temporal patterns of milk yield (A) and 3.5\% FCM (B) by postpartum Holstein cows fed a control $(\bigcirc)$, conjugated linoleic acids-supplemented $(\nabla)$, or trans- $\mathrm{C}_{18: 1}$ (TRANS)-supplemented ( $\square$ ) diet. See Table 1 for composition of fat supplements. There was a treatment $\times$ week interaction (third-order polynomial, $P<0.02$ ) for milk yield.

$\times$ week interaction, third-order polynomial, $P<0.02$ ) than those for cows in the control and bCLA groups (Figure 3A). Average 3.5\% FCM weights were unaffected by dietary treatment during the first $7 \mathrm{wk}$ of lactation (Figure 3B). Mean milk protein production and concentration and SCC were similar among dietary treatment groups (Table 3).

Mean milk fat concentration was reduced $(P<0.01)$ in cows fed CLA (3.49 vs. 2.99, Table 3). Dietary CLA supplementation decreased $(P<0.05)$ milk fat content by 23,26 , and $25 \%$ at wk 5,6 , and 7 of lactation, respectively (Figure 4A). In spite of small numerical tendencies, trans $-\mathrm{C}_{18: 1}$ supplementation had no detectable effect on milk fat percentage (Table 3; Figure 4A). Dietary

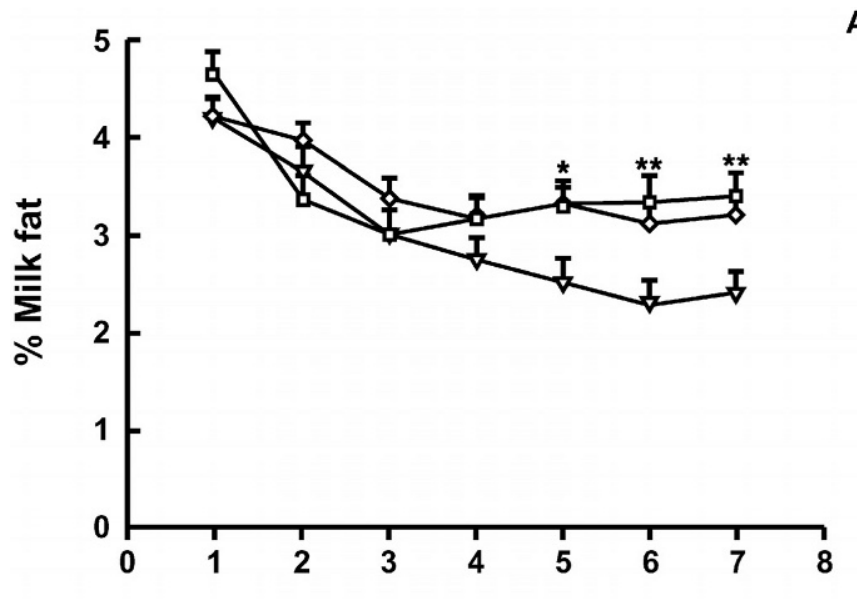

B

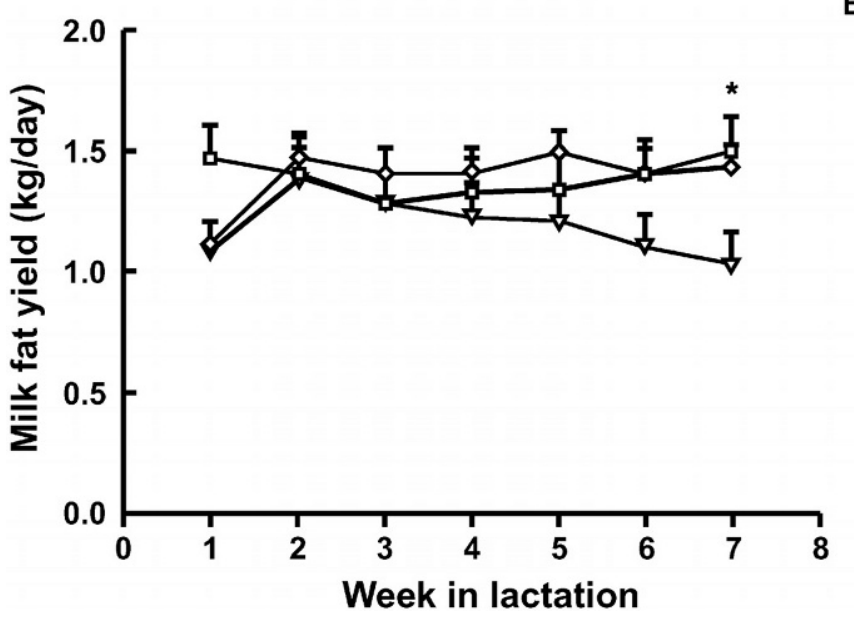

Figure 4. Temporal patterns of milk fat percentage (A) and yield (B) in postpartum Holstein cows fed a control $(\bigcirc)$, conjugated linoleic acids-supplemented $(\nabla)$, or trans- $\mathrm{C}_{18: 1}$ (TRANS)-supplemented ( $\square$ ) diet. See Table 1 for composition of fat supplements. Asterisks indicate significant treatment differences at wk $5(P<0.03), 6(P<0.01)$, and $7(P<0.01)$ for milk fat percentage, and at wk $7(P<0.03)$ for milk fat yield.

CLA, but not trans- $\mathrm{C}_{18: 1}$ mix, reduced $(P<0.02)$ milk fat yield by wk 7 of lactation (Figure $4 \mathrm{~B}$ ).

As expected, higher concentrations of CLA (namely the trans-10, cis-12 isomer) and trans- $\mathrm{C}_{18: 1}$ fatty acids were detected in milk from cows receiving the bCLA and TRANS diets, respectively (Table 4$)$. In addition, supplementation of CLA decreased $(P<0.01)$ short- to medium-chain fatty acid $\left(\mathrm{C}_{4: 0}\right.$ to $\left.\mathrm{C}_{14: 0}\right)$ concentrations and increased $(P<0.01)$ both linoleic and linolenic acid concentrations in milk fat (Table 4). There was a tendency $(P<0.06)$ for less cis-9,trans-11 CLA isomer in milk fats from CLA-supplemented than control cows (Table 4). The fatty acid profiles were derived from composite milk samples for wk 2,4 , and 7 , and therefore may not reflect precise temporal changes in milk fatty acid composition. 
Table 4. Least squares means of fatty acids in milk fat from Holstein cows fed diets containing calcium salts of conjugated linoleic acid (CLA) or trans-octadecenoic acid isomers (TRANS). ${ }^{1}$

\begin{tabular}{|c|c|c|c|c|c|c|}
\hline \multirow[b]{2}{*}{ Fatty acid } & \multicolumn{3}{|c|}{ Treatment } & \multirow[b]{2}{*}{ SEM } & \multicolumn{2}{|c|}{ Contrasts $^{2} P$} \\
\hline & Control & CLA & TRANS & & $\mathrm{C} 1$ & $\mathrm{C} 2$ \\
\hline & \multicolumn{3}{|c|}{$\longrightarrow(\mathrm{g} / 100 \mathrm{~g}$ of fatty acids $)-$} & & & \\
\hline $\mathrm{C}_{4: 0}$ to $\mathrm{C}_{14: 0}$ & 17.86 & 14.65 & 16.17 & 0.456 & $<0.001$ & $<0.007$ \\
\hline $\mathrm{C}_{4}$ & 3.09 & 3.16 & 3.21 & 0.105 & NS & NS \\
\hline $\mathrm{C}_{5}$ & 0.03 & 0.03 & 0.03 & 0.002 & NS & NS \\
\hline $\mathrm{C}_{6}$ & 1.65 & 1.31 & 1.52 & 0.074 & $<0.001$ & $<0.02$ \\
\hline $\mathrm{C}_{7}$ & 0.02 & 0.01 & 0.01 & 0.002 & $<0.001$ & $<0.02$ \\
\hline $\mathrm{C}_{8}$ & 0.94 & 0.67 & 0.81 & 0.005 & $<0.001$ & $<0.002$ \\
\hline $\mathrm{C}_{9}$ & 0.03 & 0.02 & 0.02 & 0.003 & $<0.001$ & $<0.004$ \\
\hline $\mathrm{C}_{10}$ & 1.97 & 1.37 & 1.63 & 0.146 & $<0.001$ & $<0.001$ \\
\hline $\mathrm{C}_{11}$ & 0.04 & 0.02 & 0.03 & 0.005 & $<0.001$ & $<0.002$ \\
\hline $\mathrm{C}_{12}$ & 2.16 & 1.58 & 1.80 & 0.156 & $<0.001$ & $<0.001$ \\
\hline $\mathrm{C}_{13}$ & 0.07 & 0.05 & 0.06 & 0.006 & $<0.003$ & $<0.02$ \\
\hline $\mathrm{C}_{14}$ & 7.87 & 6.43 & 7.07 & 0.370 & $<0.001$ & $<0.006$ \\
\hline $\mathrm{C}_{14: 1}$ & 0.43 & 0.28 & 0.36 & 0.079 & $<0.001$ & $<0.001$ \\
\hline $\mathrm{C}_{15: 0}$ & 0.71 & 0.64 & 0.64 & 0.122 & $<0.03$ & $<0.03$ \\
\hline $\mathrm{C}_{16: 0}$ & 27.64 & 26.27 & 27.15 & 0.250 & $<0.001$ & NS \\
\hline $\mathrm{C}_{16: 1}$ & 1.08 & 0.94 & 0.96 & 0.136 & $<0.001$ & $<0.001$ \\
\hline $\mathrm{C}_{17: 0}$ & 0.56 & 0.58 & 0.53 & 0.052 & NS & $<0.03$ \\
\hline $\mathrm{C}_{18: 0}$ & 15.36 & 17.51 & 16.30 & 0.312 & $<0.001$ & $<0.03$ \\
\hline Trans $-\mathrm{C}_{18: 1}$ isomers & 6.21 & 6.36 & 7.48 & 0.223 & NS & $<0.001$ \\
\hline trans -5 & 0.05 & 0.06 & 0.06 & 0.001 & $<0.009$ & $<0.001$ \\
\hline trans- 6 & 0.04 & 0.05 & 0.05 & 0.001 & $<0.001$ & $<0.001$ \\
\hline trans $-7-8$ & 0.77 & 0.88 & 0.91 & 0.020 & $<0.001$ & $<0.001$ \\
\hline trans-9 & 1.32 & 1.46 & 1.66 & 0.031 & $<0.002$ & $<0.001$ \\
\hline trans -10 & 1.08 & 1.17 & 1.36 & 0.059 & NS & $<0.001$ \\
\hline trans-11 & 1.60 & 1.19 & 1.81 & 0.051 & $<0.001$ & $<0.004$ \\
\hline trans-12 & 0.81 & 0.91 & 0.99 & 0.032 & $<0.02$ & $<0.001$ \\
\hline trans -16 & 0.53 & 0.61 & 0.62 & 0.008 & $<0.001$ & $<0.001$ \\
\hline$c i s-9$ & 20.45 & 21.91 & 20.63 & 0.389 & $<0.01$ & NS \\
\hline cis -10 & 0.35 & 0.37 & 0.39 & 0.026 & NS & NS \\
\hline$c i s-11$ & 0.82 & 0.89 & 0.82 & 0.021 & $<0.02$ & NS \\
\hline cis-12 & 0.65 & 0.92 & 0.69 & 0.017 & $<0.001$ & NS \\
\hline cis-13 & 0.14 & 0.16 & 0.15 & 0.050 & $<0.001$ & NS \\
\hline cis-15 & 0.16 & 0.18 & 0.18 & 0.003 & $<0.004$ & $<0.001$ \\
\hline CLA isomers & 0.49 & 0.60 & 0.49 & 0.002 & $<0.001$ & NS \\
\hline cis-9, trans -11 & 0.29 & 0.27 & 0.30 & 0.008 & NS & NS \\
\hline trans -10, cis -12 & 0.04 & 0.09 & 0.04 & 0.059 & $<0.001$ & NS \\
\hline Other CLA & 0.14 & 0.22 & 0.15 & 0.004 & $<0.001$ & NS \\
\hline $\mathrm{C}_{18: 2}$ & 2.92 & 3.53 & 2.76 & 0.046 & $<0.001$ & $<0.01$ \\
\hline $\mathrm{C}_{18: 3}$ & 0.26 & 0.31 & 0.26 & 0.004 & $<0.001$ & NS \\
\hline Other $^{3}$ & 6.63 & 6.42 & 6.47 & 0.085 & NS & NS \\
\hline
\end{tabular}

${ }^{1}$ Values represent an average of wk 2, 4, and 7 of lactation.

${ }^{2}$ Contrasts: $\mathrm{C} 1=$ control vs. CLA; $\mathrm{C} 2$ = control vs. TRANS.

${ }^{3}$ Fatty acids identified based on previous reports using the same column, but for which there were no standards in this analysis.

\section{Metabolic Responses}

Week $\times$ treatment interactions were detected for plasma NEFA $(P<0.01)$ and BHBA $(P<0.02)$ concentrations (Figure 5). At wk 1 postpartum, cows fed the CLAsupplemented diet had greater plasma NEFA and BHBA concentrations than those in the control group.

Mean liver lipid and TAG concentrations increased $(P<0.01)$ between $d 2$ and 14 postpartum, and then decreased by d 28 postpartum (Figure 6). In spite of numerical tendencies, mean hepatic lipid and TAG con- centrations did not differ among the diets. Concentrations of glucose in plasma were unaffected by dietary treatment (Figure 7A). Plasma insulin concentration decreased $(P<0.01)$ from $0.41 \pm 0.02 \mathrm{ng} / \mathrm{mL}$ at wk -1 to $0.32 \pm 0.02 \mathrm{ng} / \mathrm{mL}$ at wk 1 postpartum (Figure 7B) and was greater $(P<0.05)$ in cows fed the TRANS diet than those fed the control diet at $6 \mathrm{wk}$ of lactation.

Steady-state concentration of hepatic mRNA encoding $\mathrm{PC}$ was greater $(P<0.01)$ for the TRANS treatment group than for the control group at d 2, 14, and 28 postpartum (Figure 8A). The abundance of liver PEPCK 

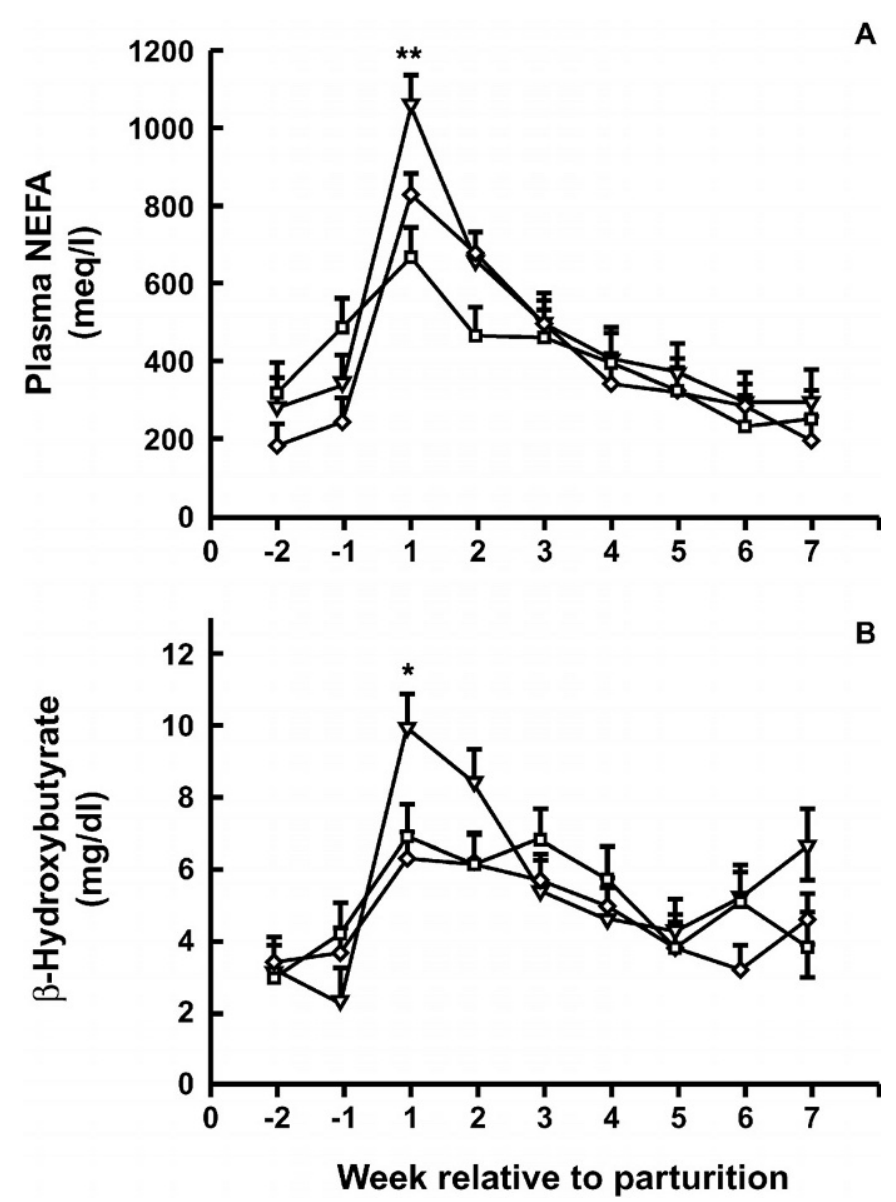

Figure 5. Plasma NEFA (A) and BHBA (B) concentrations by week relative to parturition in Holstein cows fed a control $(O)$, conjugated linoleic acids-supplemented $(\nabla)$, or trans- $\mathrm{C}_{18: 1}$ (TRANS)-supplemented $(\square)$ diet. Asterisks indicate significant treatment differences at wk 1 for plasma NEFA $(P<0.01)$ and BHBA $(P<0.02)$.

mRNA transcript was greater $(P<0.01)$ in cows fed the TRANS diet than those fed the control diet at $d 14$ postpartum (Figure 8B).

\section{DISCUSSION}

In the present study, 10-wk fat supplementation did not appear to have an adverse effect on the cow's health or production performance. Between wk 4 and 6 of lactation, DMI was lower in cows fed the TRANS diet compared with those fed the control diet. Results are consistent with other studies that have shown a decrease in DMI when cows were infused with trans (Romo et al., 2000) or long-chain (Bremmer et al., 1998) fatty acids. The mechanism by which dietary fat supplements alter DMI in dairy cows is unclear and may vary depending upon the profile of long-chain fatty acids that are available for intestinal absorption. In a recent cattle study (Choi and Palmquist, 1996), dietary supplementation
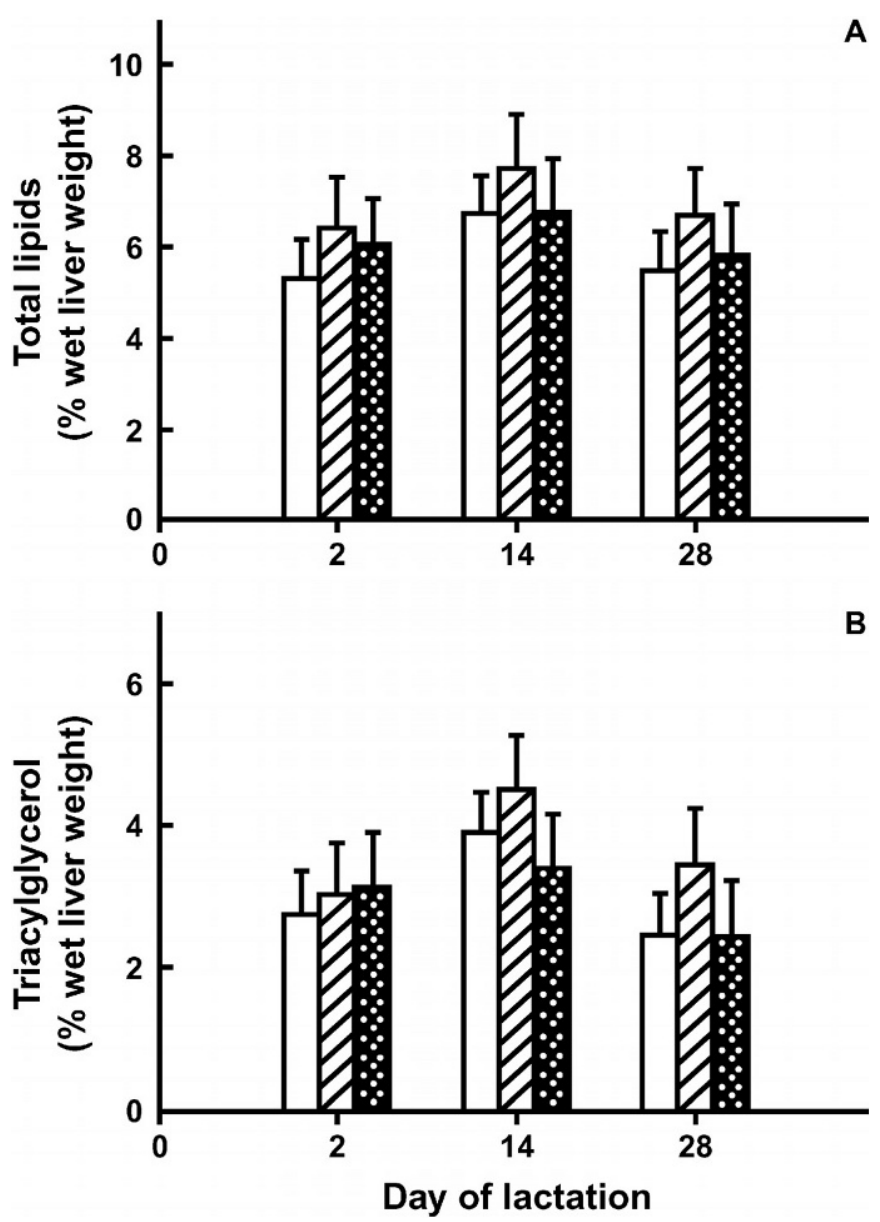

Figure 6. Liver lipid (A) and triacylglycerol (B) concentrations by day of lactation in Holstein cows fed a control $(\square)$, conjugated linoleic acids-supplemented (diagonal line), or trans- $\mathrm{C}_{18: 1}$ (TRANS)-supplemented (cross hatch) diet.

of fat increased plasma cholecystokinin, which may decrease feed intake through inhibition of reticuloruminal motility (Matzinger et al., 2000).

This study extends previous observations on milk fat depression by abomasal infusion of CLA to lactating dairy cows (Chouinard et al., 1999; Baumgard et al., 2000). Unlike CLA, dietary supplementation of trans$\mathrm{C}_{18: 1}$ isomers had no detectable effect on milk fat percentage and yield during the first 7 wk of lactation. This is consistent with a recent report that calciumprotected CLA supplements were more effective at reducing milk fat content than were calcium salts of trans fatty acids (Moallem et al., 2002). Available evidence indicates that supplemental CLA likely decreases milk fat content through inhibition of de novo fatty acid synthesis in the mammary gland, as reflected by decreased short-chain fatty acid concentrations in milk (Loor and Herbein, 1998) and reduced mammary lipogenic rate in CLA-treated cows (Baumgard et al., 2002). 

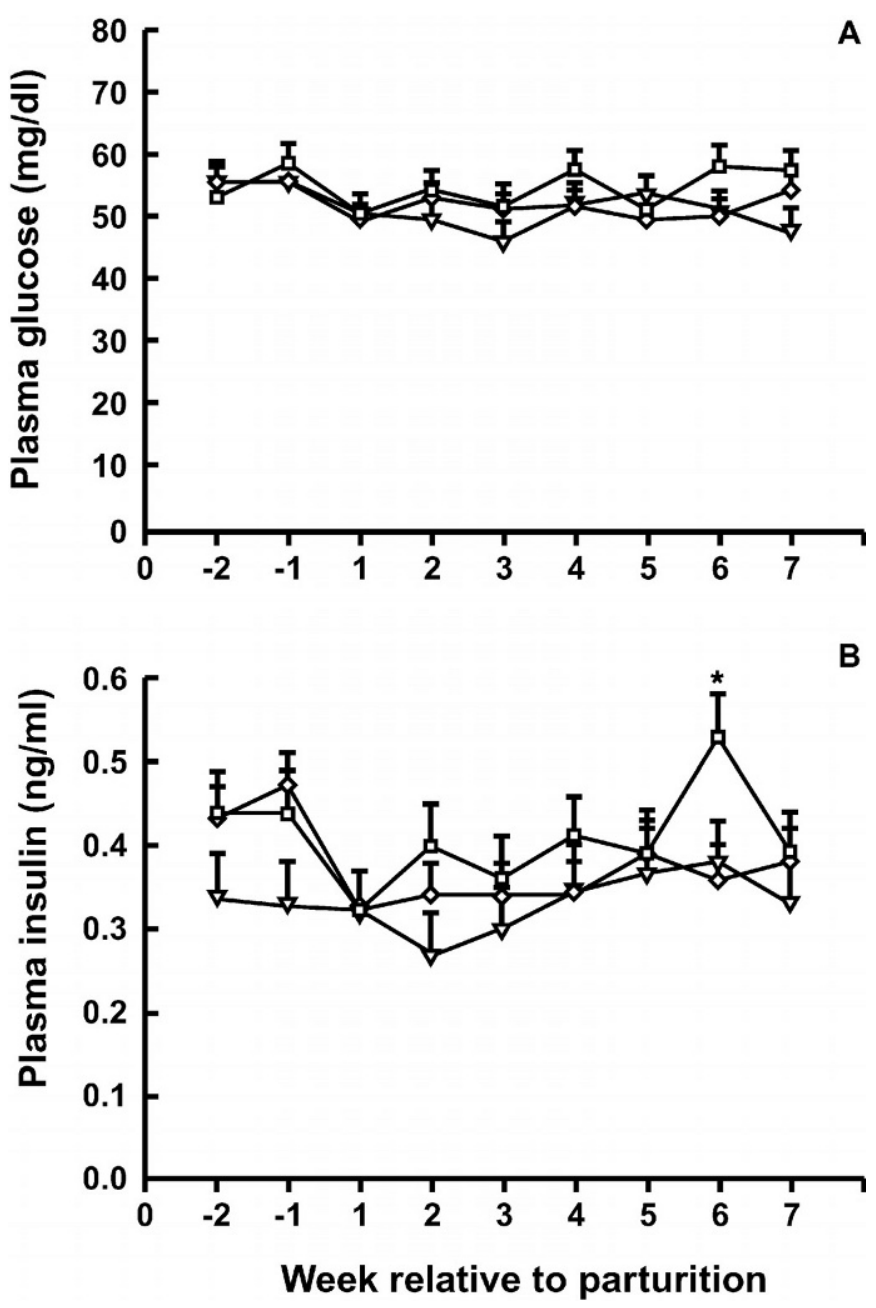

Figure 7. Plasma glucose (A) and insulin (B) concentrations by week relative to parturition in Holstein cows fed a control $(O)$, conjugated linoleic acids-supplemented $(\nabla)$, or trans $-\mathrm{C}_{18: 1}$ (TRANS)-supplemented $(\square)$ diet. A treatment effect was detected $(P<0.02)$ for plasma insulin at wk 6 of lactation.

Concentrations of NEFA and BHBA in plasma were greater in cows fed the CLA-supplemented diet than those fed the control diet at 1 wk of lactation. Results are consistent with rodent studies (Park et al., 1997), but disagree with most cattle studies, which have shown little or no effect of supplemental CLA on basal lipolysis (Baumgard et al., 2000, 2002). This discrepancy between the present study and previous reports in cattle may be due to differences in the duration or stage of lactation when those studies were conducted. Because plasma NEFA concentration is a reliable index of the magnitude of adipose fat mobilization (Bauman et al., 1988), the current finding on plasma NEFA concentration would indicate that periparturient CLA supplementation might transiently enhance lipolysis shortly after calving in postpartum Holstein cows.
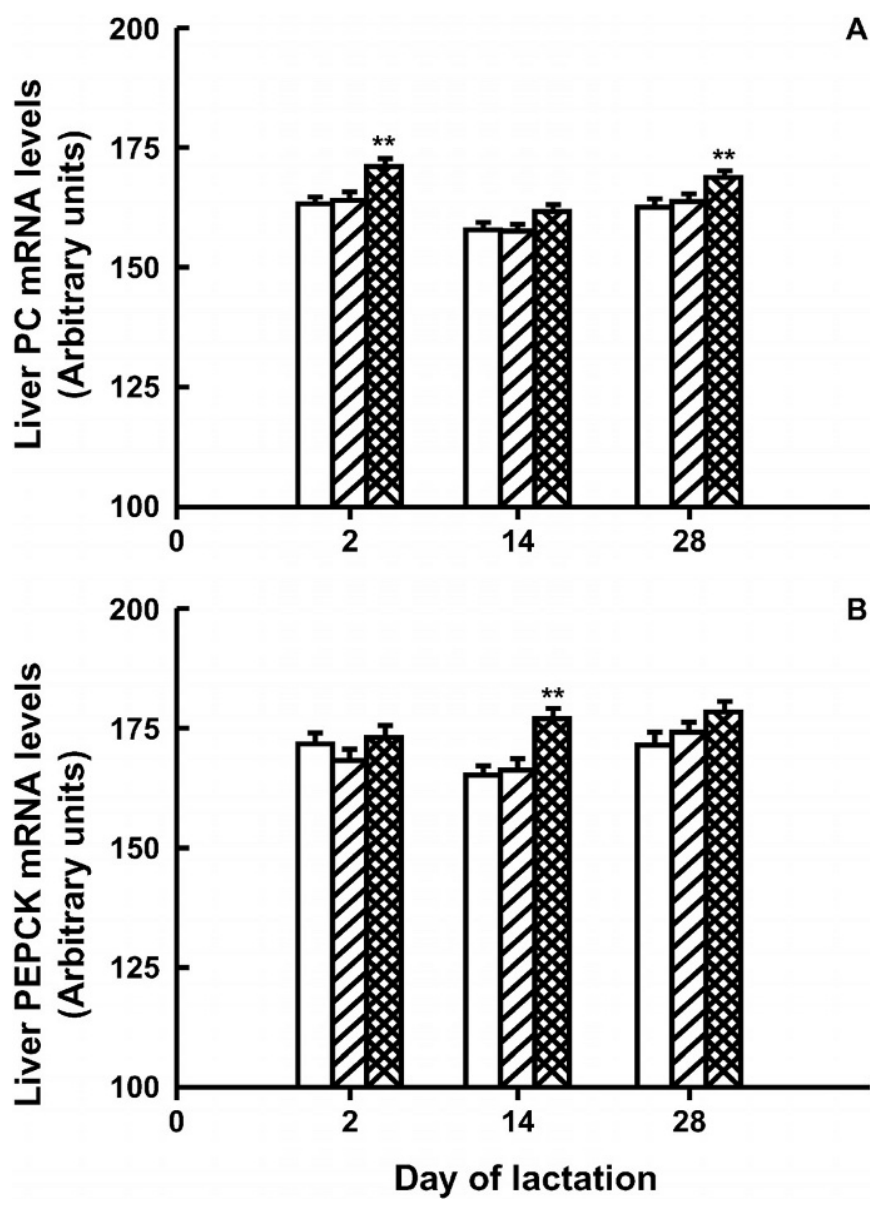

Figure 8. Steady-state concentrations of hepatic mRNA encoding pyruvate carboxylase (PC; A) and phosphoenolpyruvate carboxykinase (PEPCK; B) by day of lactation in Holstein cows fed a control $(\square)$, conjugated linoleic acids-supplemented (diagonal line), or trans$\mathrm{C}_{18: 1}$ (TRANS)-supplemented (cross hatch) diet. Asterisks indicate significant treatment differences at d $2(P<0.01)$ and $28(P<0.01)$ for PC mRNA, and at d $14(P<0.01)$ for PEPCK mRNA.

The observation that periparturient CLA supplementation failed to alter peripheral glucose concentration is consistent with previous cattle (Baumgard et al., 2002) and mice (West et al., 2000) data. However, the finding that supplemental trans- $\mathrm{C}_{18: 1}$ monoenes failed to increase plasma glucose concentration is difficult to interpret in light of the induction of PC and PEPCK mRNA transcripts by dietary trans fatty acids. At any given time, plasma glucose concentration represents a steady-state level of blood glucose, which may not be indicative of how much glucose is being produced de novo and how much of it is being cleared from circulation. On the other hand, Northern blot analysis detects steady-state levels of a target gene, but does not provide adequate information as to how the enzymatic activity may be altered by a given treatment. Consequently, the apparent discrepancy between the amount of an 
enzyme and the concentration of its metabolic product may reflect the combined differences between peripheral processing of the metabolite and the enzymatic activity due to treatment.

\section{CONCLUSION}

Feeding calcium salts of CLA to early lactation Holstein cows depressed milk fat concentration after wk 4 of lactation, whereas supplementation of calcium salts of trans-octadecenoic fatty acids did not induce detectable alteration in milk fat content during the first 7 wk of lactation. Concentrations of NEFA and BHBA in blood were greater in cows fed the CLA-supplemented diet than those fed a control diet at wk 1 of lactation. Steady-state concentrations of hepatic mRNA encoding PC and PEPCK were upregulated by dietary trans fatty acids. Results indicate that feeding calcium salts of CLA and trans octadecenoic acids to postpartum Holstein cows may alter lipid and glucose metabolism through distinct mechanisms.

\section{ACKNOWLEDGMENTS}

The authors express their appreciation to Bioproducts Inc. for partial financial support and the generous gift of calcium salts of CLA and trans- $\mathrm{C}_{18: 1}$ isomers, and to the University of Florida Dairy Research Unit staff for management of the cows.

\section{REFERENCES}

Bauman, D. E., C. J. Peel, W. D. Steinhour, P. J. Reynolds, H. F. Tyrrell, A. C. G. Brown, and G. L. Haaland. 1988. Effect of bovine somatotropin on metabolism of lactating dairy cows: Influence on rates of irreversible loss and oxidation of glucose and nonesterified fatty acids. J. Nutr. 118:1031-1040.

Baumgard, L. H., B. A. Corl, D. A. Dwyer, A. Saebo, and D. E. Bauman. 2000. Identification of the conjugated linoleic acid isomer that inhibits milk fat synthesis. Am. J. Physiol. 278(Suppl.):R179R184.

Baumgard, L. H., E. Matitashvili, B. A. Corl, D. A. Dwyer, and D. E. Bauman. 2002. trans-10, cis-12 conjugated linoleic acid decreases lipogenic rates and expression of genes involved in milk lipid synthesis. J. Dairy Sci. 85:2155-2163.

Baumgard, L. H., J. K. Sangster and D. E. Bauman. 2001. Milk fat synthesis in dairy cows is progressively reduced by increasing supplemental amounts of trans-10, cis-12 conjugated linoleic acid (CLA). J. Nutr. 131:1764-1769.

Bell, A. W. 1995. Regulation of organic nutrient metabolism during the transition from late pregnancy to early lactation. J. Anim. Sci. 73:2804-2819.

Bremmer, D. R., L. D. Ruppert, J. H. Clark, and J. K. Drackley. 1998. Effects of chain length and unsaturation of fatty acid mixtures infused into the abomasums of lactating dairy cows. J. Dairy Sci. 81:176-188.

Chin, S. F., J. M. Storkson, K. J. Albright, M. E. Cook, and M. W. Pariza. 1994. Conjugated linoleic acid is a growth factor for rats as showm by enhanced weight gain and improved feed efficiency. J. Nutr. 124:2344-2349.
Chin, S. F., W. Liu, J. M. Storkson, Y. L. Ha, and M. P. Pariza. 1992. Dietary sources of conjugated dienoic isomers of linoleic acid, a newly recognized class of anticarcinogens. J. Food Compos. Anal. 5:185-197.

Choi, B. R., and D. L. Palmquist. 1996. High fat diets increase plasma cholecystokinin and pancreatic polypeptide, and decrease plasma insulin and feed intake in lactating cows. J. Nutr. 126:2913-2919.

Chouinard, P. Y., L. Corneau, A. Saebo, and D. E. Bauman. 1999. Milk yield and composition during abomasal infusion of conjugated linoleic acids in dairy cows. J. Dairy Sci. 82:2737-2745.

Christie, W. W. 1982. A simple procedure for rapid transmethylation of glycerolipids and cholesterol esters. J. Lipid Res. 23:1072-1075.

Cook, M. E., C. C. Miller, Y. Park, and M. W. Pariza. 1993. Immune modulation by altered nutrient metabolism: Nutritional control of immune-induced growth depression. Poult. Sci. 72:1301-1305.

DeLany, J. P., F. Blohm, A. A. Truett, J. A. Scimeca, and D. B. West. 1999. Conjugated linoleic acid rapidly reduces body fat content in mice without affecting energy intake. Am. J. Physiol. 276(Suppl.):R1172-R1179.

Drackley, J. K. 1999. Biology of dairy cows during the transition period: The final frontier? J. Dairy Sci. 82:2259-2273.

Drackley, J. K., J. J. Veenhuzen, M. J. Richard, and J. W. Young. 1991. Metabolic changes in blood and liver of dairy cows during either feed restriction or administration of 1,3-butanediol. J. Dairy Sci. 74:4254-4264.

Feinberg, A. P., and B. Vogelstein. 1983. A technique for radiolabeling DNA restriction endonuclease fragments to high specific activity. Anal. Biochem. 136:6-13.

Foster, L. B., and R. T. Dunn. 1973. Stable reagent for the determination of serum triglyceride by colorimetric Hantzsch condensation. Methods Clin. Chem. 19:338-340.

Giesy, J. G., M. A. McGuire, B. Shafil, and T. W. Hanson. 2002. Effect of dose of calcium salts of conjugated linoleic acid (CLA) on percentage and fatty acid content of milk fat in midlactation Holstein cows. J. Dairy Sci. 85:2023-2029.

Griinari, J. M., B. A. Cori, S. H. Lacy, P. Y. Chouinard, K. V. V. Nurmela, and D. E. Bauman. 2000. Conjugated linoleic acid is synthesized endogenously in lactating dairy cows by delta (9)desaturase. J. Nutr. 130:2285-2291.

Griinari, J. M., D. A. Dwyer, M. A. McGuire, D. E. Bauman, D. L. Palmquist, and K. V. V. Nurmela. 1998. Trans-octadecenoic acids and milk fat depression in lactating dairy cows. J. Dairy Sci. 81:1251-1261.

Grummer, R. R. 1993. Etiology of lipid-related metabolic disorders in periparturient dairy cows. J. Dairy Sci. 76:3882-3896.

Ip, C. 1997. Review of the effects of trans fatty acids, oleic acid, n3 polyunsaturated fatty acids, and conjugated linoleic acid on mammary carcinogenesis in animals. Am. J. Clin. Nutr. 66:15235-15295.

Loor, J. J., and J. H. Herbein. 1998. Exogenous conjugated linoleic acid isomers reduce bovine milk fat concentration and yield by inhibiting de novo fatty acid synthesis. J. Nutr. 128:2411-2419.

Ma, D., A. Wierzbicki, C. Field, and M. T. Clandinin. 1999. Conjugated linoleic acid in Canadian dairy and beef products. J. Agric. Food Chem. 47:1956-1960.

Malven, P. V., H. H. Head, R. J. Collier, and F. C. Buoenomo. 1987. Periparturient changes in secretion and mammary uptake of insulin and concentrations of insulin and insulin-like growth factors in milk of dairy cows. J. Dairy Sci. 70:2254-2262.

Matzinger, D., L. Degen, J. Drewe, J. Meuli, R. Duebendorfer, N. Ruckstuhl, M. D'Amato, L. Rovati, and C. Beglinger. 2000. The role of long chain fatty acids in regulating food intake and cholecystokinin release in humans. Gut 46:688-693.

Moallem, U., B. Teter, L. Piperova, J. Sampugna, and R. Erdman. 2002. Calcium salts of conjugated linoleic acid were more effective than calcium salts of trans fatty acids in reducing milk fat of lactating cows. J. Dairy Sci. 85(Suppl. 1):316. (Abstr.)

Nicolosi, R., E. Rogers, D. Kritchevsky, J. A. Scimeca, and P. Huth. 1997. Dietary conjugated linoleic acid reduces plasma lipoproteins and early aortic atherosclerosis in hypercholesterolemic hamsters. Artery 22:266-277. 
NRC. 2001. Nutrient Requirements of Dairy Cattle. 7th rev. ed. Natl. Acad. Sci., Washington, DC.

Park, Y., K. Albright, W. Liu, J. Storkson, M. Cook, and M. Pariza. 1997. Effect of conjugated linoleic acid on body composition in mice. Lipids 32:853-858.

Romo, G. A., R. A. Erdman, B. B. Teter, J. Sampugna, and D. P. Casper. 2000. Milk composition and apparent digestibilities of dietary fatty acids in lactating dairy cows abomasally infused with cis or trans fatty acids. J. Dairy Sci. 83:2609-2619.
Sukjija, S., and D. L. Palmquist. 1988. Rapid method for the determination of total fatty acid content and composition of feedstuffs and feces. J. Agric. Food Chem. 36:1202-1206.

West, D. B., F. Y. Blohm, A. A. Truett, and J. P. DeLany. 2000 Conjugated linoleic acid persistently increases total energy expenditure in $\mathrm{AKR} / \mathrm{J}$ mice without increasing uncoupling protein gene expression. J. Nutr. 130:2471-2477.

Wiggans, G. R. 1986. Estimating daily yields of cows milked three times a day. J. Dairy Sci. 69:2935-2940. 